\title{
IDENTIFIKASI DAERAH RISIKO BENCANA LONGSOR DI KOTA BOGOR
}

\section{Identification of Landslide Risk in the City of Bogor}

\author{
M. Galih Permadi1)*, Boedi Tjahjono2) dan Dwi Putro Tejo Baskoro') \\ 1) Program Studi Ilmu Mitigasi Bencana Kerusakan Lahan, Sekolah Pascasarjana, Institut Pertanian Bogor, \\ Kampus IPB Dramaga, Bogor 16680 \\ 2) Departemen Ilmu Tanah dan Sumberdaya Lahan, Fakultas Pertanian, Institut Pertanian Bogor, Jl. Meranti \\ Kampus IPB Dramaga, Bogor 16680
}

\begin{abstract}
Landslide is one of the disasters that often hit Indonesia. Data collected from BPBD Office of Bogor City also shows that landslide events ranked first out of 6 types of disasters in Bogor City; in 2017 there were 179 landslides (40.5\%) of the 442 recorded disaster events. To support development programs in the city, landslide risk research is needed. This study aimed to assess and map the risk of landslides in Bogor City and formulate mitigation recommendations. The method used is the Multi Criteria Evaluation where the weights and scores of each parameter are obtained from the Analytical Hierarchy Process (AHP). The results obtained show that the highest level of susceptibility and landslide hazard is in the South Bogor District, this is in accordance with the landform conditions in the region, where $60.5 \%$ of the area has landforms with steep slopes i.e. denudational volcanic cones, river banks, and valleys with alluvial terrace. However, for the highest risk, the extent area is located in North Bogor District. This is due to the dominance of residential and high population, so the vulnerability factor is an indicator of rising risk values. For Bogor City which is dominant with residential, recommended mitigation include 3 types of engineering, namely civil, vegetative, and social for medium and high risk classes. Bogor Selatan sub-district in this case is the district with the most extensive area to implement mitigation measures.
\end{abstract}

Keywords: Hazards, landforms, mitigation, vulnerabilities

ABSTRAK

Bencana longsor merupakan salah satu bencana yang sering melanda Indonesia. Data yang dihimpun dari BPBD Kota Bogor, menunjukkan pula bahwa kejadian longsor menempati urutan pertama dari 6 jenis bencana yang ada di Kota Bogor; pada tahun 2017 terdapat 179 kejadian longsor (40.5\%) dari 442 kejadian bencana yang tercatat. Guna mendukung program pembangunan di kota ini, penelitian risiko longsor sangat diperlukan. Penelitian ini bertujuan untuk menilai dan memetakan risiko longsor Kota Bogor dan merumuskan rekomendasi mitigasinya. Metode yang digunakan adalah Multi Criteria Evaluation dimana bobot dan skor dari setiap parameter diperoleh dari Analytical Hierarchy Process (AHP). Hasil yang diperoleh menunjukkan bahwa tingkat kerawanan dan bahaya longsor tertinggi luasannya terdapat di Kecamatan Bogor Selatan, hal ini sesuai dengan kondisi landform yang ada di wilayah tersebut, dimana $60.5 \%$ wilayahnya merupakan bentuklahan lereng bawah kerucut vulkanik denudasional, tebing sungai, serta lembah dan teras alluvial. Namun demikian untuk risiko tertinggi luasannya terdapat di Kecamatan Bogor Utara. Hal ini dikarenakan dominasi penggunaan lahan permukiman dan jumlah penduduk yang tinggi, sehingga faktor kerentanan menjadi indikator naiknya nilai risiko. Untuk Kota Bogor yang dominan dengan penggunaan lahan permukiman, arahan mitigasi yang direkomendasikan meliputi perlakuan teknik sipil, teknik vegetatif, dan teknik sosial pada kelas risiko sedang dan tinggi. Kecamatan Bogor Selatan dalam hal ini merupakan kecamatan yang paling luas areanya untuk diterapkan tindakan mitigasi.

Kata kunci: Bahaya, bentuklahan, mitigasi, kerentanan

\section{PENDAHULUAN}

Bencana longsor merupakan salah satu bencana yang sering melanda Indonesia di musim hujan. Kejadian longsor tercatat berada di urutan kedua dari kejadian bencana paling sering terjadi di Indonesia setelah banjir. Data yang tercatat oleh Badan Nasional Penanggulangan Bencana (BNPB) menunjukkan bahwa trend terhadap bencana banjir dan longsor terus mengalami peningkatan hingga BNPB merilis data bencana tertinggi tahun 2016. Kejadian bencana pada tahun 2016 tercatat ada 2,342 peristiwa dan merupakan kejadian tertinggi sejak pencatatan kejadian bencana pada tahun 2002. Ada sebanyak $92 \%$ dari seluruh kejadian bencana didominasi oleh bencana hidrometeorologi yaitu berupa bencana banjir, longsor, dan angin puting beliung (BNPB, 2016a). Pada kasus bencana longsor, tercatat ada 612 kejadian selama tahun 2016 yang menyebabkan 188 jiwa meninggal dunia. Selain itu tingginya kerentanan juga menyebabkan banyak menimbulkan korban jiwa. Diperkirakan ada 40.9 juta jiwa di Indonesia yang terpapar oleh bahaya longsor pada kelas bahaya sedang dan tinggi (BNPB, 2016b). Data yang dihimpun dari BPBD Kota Bogor (2017), menunjukkan bahwa kejadian longsor menempati urutan pertama sebagai bencana yang paling banyak terjadi (dari 6 jenis bencana), dimana total kejadian pada tahun 2017 ada sebanyak 179 kejadian $(40.5 \%)$ dari 442 kejadian bencana yang tercatat. 
Meningkatnya kejadian bencana longsor bukan hanya akibat perubahan iklim yang ekstrim saja, namun penyebab utama lain adalah terjadinya alih fungsi lahan, khususnya dari lahan hutan menjadi non hutan. Dengan berjalannya waktu kini proses alih fungsi lahan telah membentuk pola baru dari pemanfaatan ruang. Menurut Ramlan et al. (2015) pola pemanfataan ruang merupakan dampak dari interaksi faktor sosial dan ekonomi yang berlangsung sejalan dengan perkembangan ruang dan waktu. Alih fungsi lahan telah menjadikan urbanisasi yang berlangung cepat karena kebutuhan terhadap lahan meningkat terutama untuk lahan permukiman.

Kasus peningkatan alih fungsi lahan yang dikaitkan dengan kejadian bencana longsor menjadi sorotan yang cukup serius oleh peneliti, akademisi, hingga pemerintah. Sebagai respon terhadap hal ini, beberapa DAS dimasukkan ke dalam kategori "super prioritas", yang artinya harus sesegera mungkin dapat dipulihkan kembali kondisi ekologinya. Dalam rencana strategis Direktorat Jenderal Pengendalian Daerah Aliran Sungai dan Hutan Lindung tahun 2015 yang dikeluarkan oleh KLHK (2015) telah memasukkan dua DAS yang melewati Kota Bogor yaitu DAS Ciliwung dan DAS Cisadane sebagai DAS yang perlu mendapat prioritas penanganan untuk tahun 20152019.

Longsor selama ini dikenal sebagai kejadian yang paling mematikan dan banyak menelan korban jiwa. Curah hujan yang tinggi, morfologi yang sangat beragam, serta alih fungsi lahan yang tinggi menyebabkan Kota Bogor menjadi kota yang juga rawan terhadap longsor. Pada kasus bencana longsor, area-area yang rawan umumnya berada di sekitar aliran sungai. Pesatnya pertumbuhan dan alih fungsi lahan menyebabkan daerah dengan lereng yang cukup curam di tebing sungai juga dibuka untuk kepentingan permukiman dan aktivitas ekonomi. Oleh karena itu trend bencana longsor dangkal (shallow landslide) di tebingtebing sekitar sungai terus meningkat. Longsor dangkal umumnya terjadi dalam skala yang kecil, namun memiliki frekuensi bencana yang tinggi. Berdasarkan hal inilah diperlukan pemetaan bahaya serta risiko longsor di Kota Bogor agar mitigasi yang tepat dapat disusun untuk menunjang pembangunan. Tujuan dari penelitian ini adalah menilai tingkat risiko longsor (risk) di Kota Bogor berbasis analisis bahaya (hazard) dan kerentanan (vulnerability), serta merumuskan rekomendasikan mitigasi (mitigation) yang dapat diterapkan di Kota Bogor.

\section{BAHAN DAN METODE}

\section{Tempat dan Waktu Penelitian}

Penelitian ini dilaksanakan dari bulan Agustus 2017 hingga bulan Januari 2018. Lokasi penelitian secara administratif meliput seluruh Kota Bogor dan terletak secara geografis di antara 106 48' BT dan 6 26' LS. Daerah yang diteliti mencakup 6 kecamatan, yaitu Kecamatan Bogor Barat, Kecamatan Bogor Selatan, Kecamatan Bogor Tengah, Kecamatan Bogor Timur, Kecamatan Bogor Utara, dan Kecamatan Tanah Sareal.

\section{Alat dan Bahan}

Bahan yang akan digunakan dalam penelitian ini mencakup data yang terkait dengan lokasi penelitian. Data tersebut di antaranya adalah data bencana longsor, citra satelit SPOT 6 (2017), citra SRTM $30 \mathrm{~m}$, peta penggunaan lahan, peta geologi, data kependudukan, kuisioner, serta bahan-bahan lain yang menunjang penelitian. Alat yang akan digunakan adalah seperangkat komputer laptop dengan piranti lunak ArcGIS 10.2, Expert Choice v11, ERDAS Imagine 14, dan Microsoft Office. Untuk penelitian lapang digunakan alat smartphone dengan software Avenza Map, kamera digital, dan alat tulis.

\section{Metode Penelitian}

Untuk mencapai tujuan penelitian ini digunakan metode Multi Criteria Evaluation, dimana nilai bobot dan skor dari setiap parameter diperoleh melalui Analytical Hierarchy Process (AHP) yang dikembangkan oleh Saaty (1977). Perangkat lunak yang digunakan untuk menjalankan metode ini meliputi Expert Choice v11 dan ArcGIS 10.2.

\section{Analisis Bahaya dan Kerentanan Longsor}

Analisis bahaya longsor diawali dengan penilaian daerah rawan longsor (susceptible areas) yang dilakukan melalui pendekatan bentuklahan (landform). Pemetaan bentuklahan (skala 1:25,000) dihasilkan melalui interpretasi data hillshade yang diturunkan dari data DEM-SRTM $30 \mathrm{~m}$. Daerah rawan longsor ditentukan berdasarkan karakteristik bentuklahan dan analisis kemiringan dan bentuk lereng dengan metode SMORPH (Shaw dan Johnson, 1995). Peta daerah rawan longsor yang dihasilkan selanjutnya digunakan sebagai subset area untuk analisis bahaya (hazard) dan kerentanan (vulnerability).

Parameter yang digunakan untuk penilaian bahaya longsor (hazard) meliputi (a) kemiringan dan bentuk lereng, (b) penggunaan lahan, dan (c) kelas dan jarak terhadap jalur transportasi. Responden pakar untuk AHP yang dipilih meliputi 5 ahli dalam di bidang ilmu kebumian dan teknologi spasial. Adapun formulasi untuk menilai bahaya longsor yang digunakan adalah sebagai berikut:

$$
\begin{gathered}
\mathrm{BL}=\left\{\left(\mathrm{W}_{\mathrm{L}} \times \mathrm{S}_{\mathrm{L}}\right)+\left(\mathrm{W}_{\mathrm{PL}} \times \mathrm{S}_{\mathrm{PL}}\right)+\left(\mathrm{W}_{\mathrm{J}} \times \mathrm{S}_{\mathrm{J}}\right)\right\} \\
\mathrm{S}_{\mathrm{L}}=\left(\left(\mathrm{W}_{\mathrm{KL}} \times \mathrm{S}_{\mathrm{KL}}\right)+\left(\mathrm{W}_{\mathrm{BL}} \times \mathrm{S}_{\mathrm{BL}}\right)\right) \\
\mathrm{S}_{\mathrm{J}}=\left(\left(\mathrm{W}_{\mathrm{KJ}} \times \mathrm{S}_{\mathrm{KJ}}\right)+\left(\mathrm{W}_{\mathrm{JJ}} \times \mathrm{S}_{\mathrm{JJ}}\right)\right)
\end{gathered}
$$

Keterangan: $\mathrm{BL}=$ Bahaya Longsor, $\mathrm{W}_{\mathrm{L}}=$ bobot lereng, $\mathrm{W}_{\mathrm{PL}}$ = bobot penggunaan lahan, $\mathrm{W}_{\mathrm{J}}=$ bobot jalan, $\mathrm{W}_{\mathrm{KL}}=$ bobot kemiringan lereng, $\mathrm{W}_{\mathrm{BL}}=$ bobot bentuk lereng, $\mathrm{W}_{\mathrm{KJ}}=$ bobot kelas jalan, $\mathrm{W}_{\mathrm{JJ}}=$ bobot jarak jalan, $\mathrm{S}_{\mathrm{L}}=$ skor Lereng, $\mathrm{S}_{\mathrm{PL}}=$ skor Penggunaan Lahan, $\mathrm{S}_{\mathrm{J}}=$ skor Jalan, $\mathrm{S}_{\mathrm{KL}}=$ skor Kemiringan Lereng, $\mathrm{S}_{\mathrm{BL}}=$ skor Bentuk Lereng, $\mathrm{S}_{\mathrm{KJ}}=$ skor Kelas Jalan, dan $\mathrm{S}_{\mathrm{JJ}}=$ skor Jarak Jalan.

Untuk penilaian kerentanan longsor (vulnerability) digunakan pendekatan penggunaan lahan dimana parameter kerentanan yang digunakan meliputi (a) kerentanan fisik, (b) kerentanan sosial, dan (c) kerentanan ekonomi. Formulasi penilaian kerentanan yang digunakan adalah sebagai berikut: 


$$
\mathrm{KL}=\left(\mathrm{W}_{\mathrm{S}} \times \mathrm{S}_{\mathrm{S}}\right)+\left(\mathrm{W}_{\mathrm{F}} \times \mathrm{S}_{\mathrm{F}}\right)+\left(\mathrm{W}_{\mathrm{E}} \times \mathrm{S}_{\mathrm{E}}\right)
$$

Keterangan: $\mathrm{KL}=$ kerentanan longsor, $\mathrm{W}_{\mathrm{S}}=$ bobot sosial, $\mathrm{W}_{\mathrm{F}}=$ bobot fisik, $\mathrm{W}_{\mathrm{E}}=$ bobot ekonomi, $\mathrm{S}_{\mathrm{S}}=$ skor kerentanan sosial, $\mathrm{S}_{\mathrm{F}}=$ skor kerentanan fisik, dan $\mathrm{S}_{\mathrm{E}}=$ skor kerentanan ekonomi.

\section{Analisis Risiko Longsor}

Risiko longsor merupakan gambaran kombinasi antara bahaya dan kerentanan yang ada di daerah penelitian. Formulasi risiko mengacu pada Perka BNPB nomor 02 Tahun 2012 tentang Pedoman Umum Pengkajian Risiko Bencana, yaitu:

$$
\mathrm{R}=\mathrm{H} \times \mathrm{V} / \mathrm{C}
$$

Dimana $\mathrm{R}=$ Risiko Bencana, $\mathrm{V}=$ Kerentanan, $\mathrm{H}=$ Bahaya, dan $\mathrm{C}=$ Kapasitas.

Dalam penelitian ini faktor kapasitas tidak diperhitungkan karena keterbatasan data kapasitas yang diperoleh. Adapun klasifikasi tingkat risiko dibagi menjadi 3 kelas, yaitu tinggi, sedang, dan rendah, dengan asumsi bahwa persebaran nilai risiko bersifat normal, sehingga nilai interval dari setiap kelas dirumuskan sebagai berikut (Dibyosaputro, 1999):

Nilai interval kelas risiko $=\frac{\text { nilai tertinggi-nilai terendah }}{\text { jumlah kelas }}$

\section{Mitigasi Bencana Longsor}

Untuk arahan mitigasi bencana longsor dibagi ke dalam tiga bentuk, yaitu secara (a) teknik sipil, (b) teknik vegetatif, dan (c) teknik sosial. Untuk mitigasi secara teknik sipil dan vegetatif mengacu pada Sari (2016) yang meliputi (a) pembuatan bangunan penguat tebing, (b) pemasangan bronjong; (c) pemasangan sumbat jurang bronjong silinder, (d) dam pengendali sistem bangunan permanen, dan (e) pembuatan saluran pengelak, sedangkan teknik vegetatif meliputi (a) menanam tanaman tahunan, (b) pembiaran semak, (c), dan menanam rerumputan. Adapun untuk teknik sosial mencakup kegiatan sosialisasi terhadap bahaya longsor dan pencegahannya. Formulasi arahan mitigasi disajikan pada Tabel 1 .

Tabel 1. Penentuan arahan teknik mitigasi longsor

\begin{tabular}{lll}
\hline Bahaya & Kerentanan & \multicolumn{1}{c}{ Arahan Teknik Mitigasi } \\
\hline Sedang & Sedang & T. Vegetatif dan T. Sipil \\
Sedang & Tinggi & T. Vegetatif, T. Sipil, T. Sosial \\
Rendah & Tinggi & T. Vegetatif dan T. Sosial \\
Tinggi & Rendah & T. Sipil \\
Tinggi & Sedang & T. Sipil \\
Tinggi & Tinggi & T. Sipil \\
\hline
\end{tabular}

\section{HASIL DAN PEMBAHASAN}

\section{Bahaya Longsor}

Berdasarkan hasil interpretasi citra SRTM dan verifikasi lapangan diperoleh data bentuklahan skala 1:25,000 seperti yang tercantum dalam Gambar 1a. Selanjutnya dari informasi tersebut bentuklahan dianalisis dengan SMORPH untuk mendapatkan daerah rawan longsor (Gambar 1b). Adapun data penggunaan lahan skala 1:25,000 dari BIG dan Citra SPOT 6 (2017) diolah untuk menghasilkan peta penggunaan lahan Kota Bogor 2017 yang ter-update dengan skala yang sama (Gambar 2). Peta rawan longsor dan peta penggunaan lahan tersebut selanjutnya digunakan untuk analisis tingkat bahaya dan kerentanan longsor.

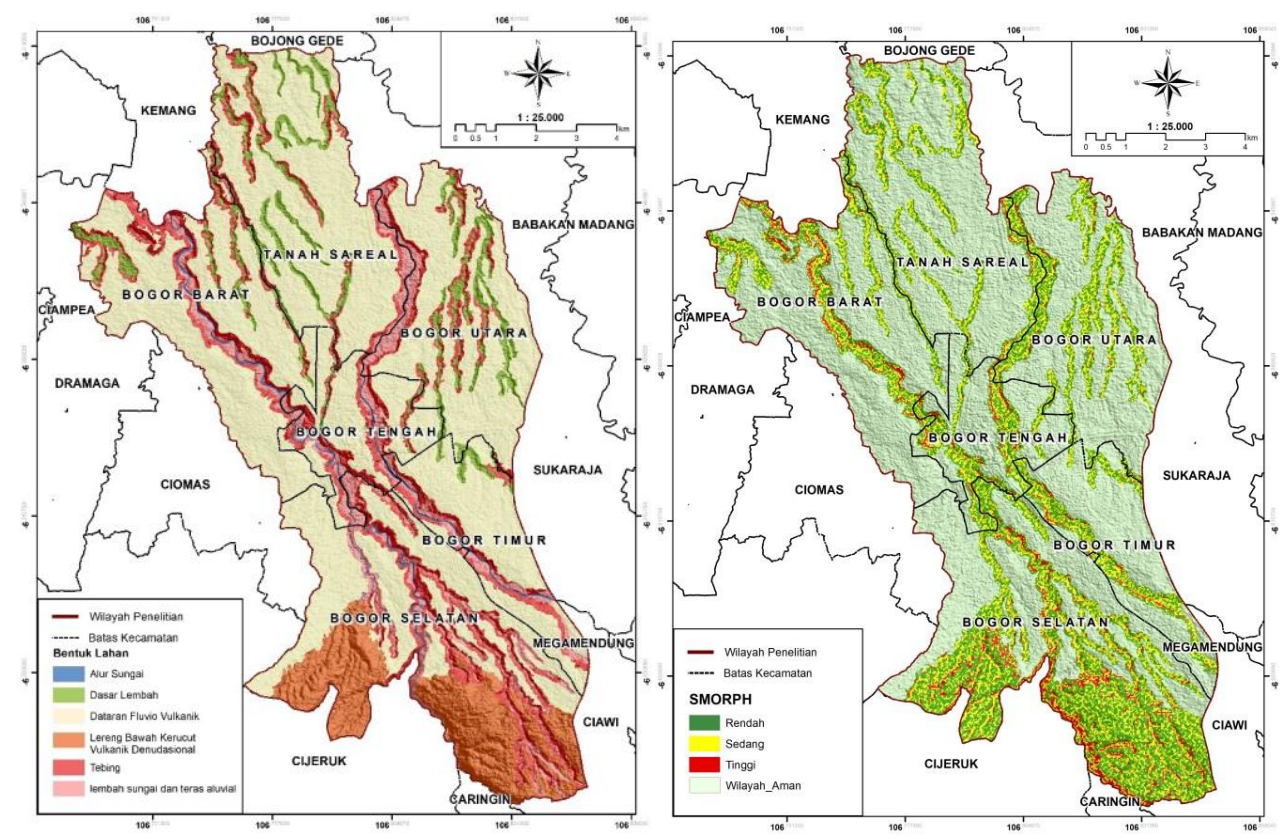

Gambar 1. (a) Peta bentuklahan (landform); (b) Peta rawan longsor hasil dari analisis SMORPH 


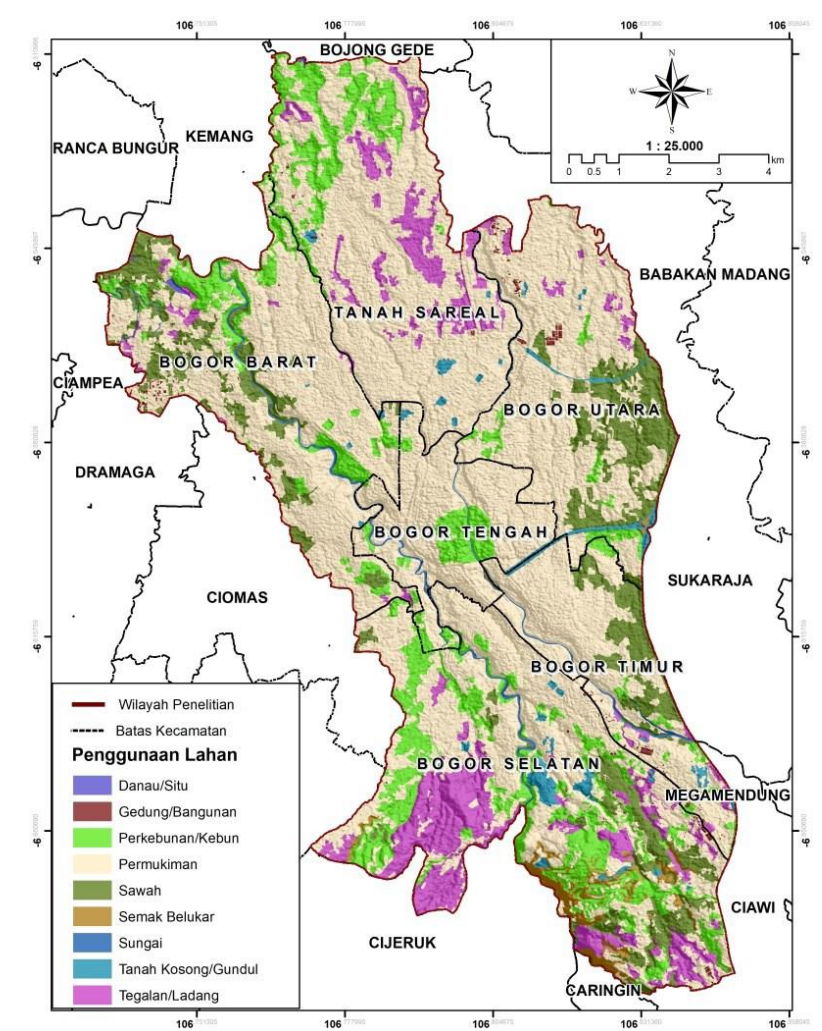

Gambar 2. Peta penggunaan lahan Kota Bogor 2017

Dengan bobot dan skor yang tercantum dalam Tabel 2 dan Persamaan 1 maka selanjutnya dapat diperoleh nilai bahaya mulai dari kelas rendah sampai dengan kelas tinggi. Hasilnya untuk kelas bahaya tinggi dan sedang yang mempunyai luasan tertinggi terdapat di Kecamatan Bogor Selatan berturut-turut sebesar $44 \%$ (bahaya tinggi) dan 42.9\% (bahaya sedang) seperti yang tersaji di Gambar 3. Besarnya luasan bahaya tinggi di wilayah Bogor Selatan ini disebabkan oleh kondisi bentuklahan yang sebagian besar berlereng curam. Bentuklahan lereng bawah kerucut vulkanik denudasional yang mempunyai luas $1,157.5$ ha dan berlereng besar, misalnya, seluruhnya berada di wilayah Kecamatan Bogor Selatan, sedangkan tebing sungai yang curam di wilayah ini juga mempunyai luasan terbesar, yaitu 114.9 ha (44\% dari total luas bahaya tinggi). Hal ini mengindikasikan bahwa wilayah Kecamatan Bogor Selatan memang memiliki potensi longsor yang secara alami sangat tinggi daripada wilayah-wilayah lain di kota Bogor.

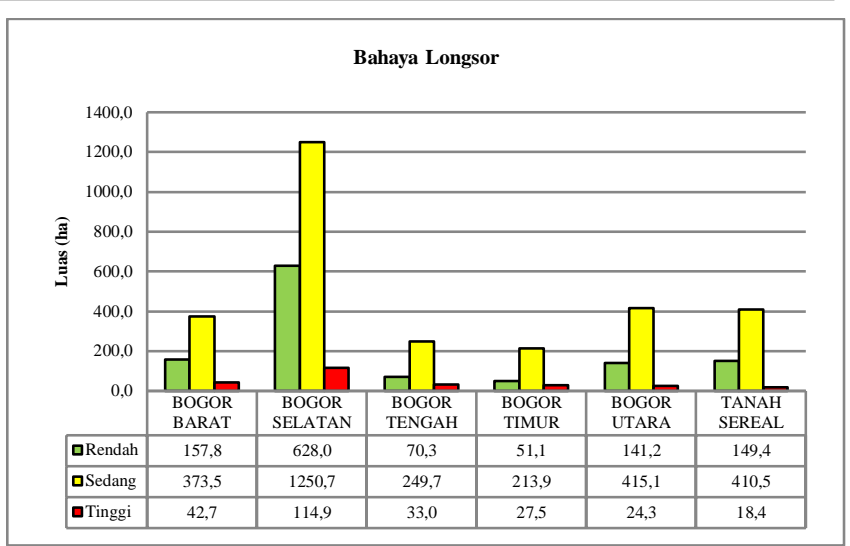

Gambar 3. Sebaran bahaya longsor di Kota Bogor

Walaupun kelas bahaya longsor tinggi yang terluas berada di kecamatan ini, namun jika dibandingkan dengan bahaya longsor kelas sedang luasnya jauh lebih dominan (1,250.7 ha). Luasnya kelas bahaya sedang di wilayah ini diakibatkan oleh parameter penggunaan lahan yang berupa perkebunan dan semak yang sangat luas dan kedua penggunaan lahan tersebut dari AHP memiliki skor yang rendah sebagai pemicu terjadinya longsor.

Untuk bahaya longsor tinggi yang memiliki luasan terendah terdapat di Kecamatan Tanah Sareal, yaitu seluas 18.4 ha atau $7 \%$ dari total luas bahaya tinggi. Wilayah Tanah Sareal merupakan wilayah yang bertopografi landai karena terdapat di atas bentuklahan Dataran Fluvio Vulkanik yang mempunyai jarak paling jauh dari Gunung Salak, yaitu mempunyai luas $1,720.5$ ha atau $74.6 \%$ dari luas total kecamatan. Persebaran kelas bahaya longsor hasil analisis secara spasial disajikan pada Gambar 4.

\section{Kerentanan Longsor}

Dalam penelitian ini terdapat 3 parameter kerentanan yang digunakan, yaitu kerentanan fisik, kerentanan sosial, dan kerentanan ekonomi. Dari hasil pengolahan AHP, bobot parameter kerentanan yang paling tinggi berada pada kerentanan fisik, yaitu sebesar $50.2 \%$, kemudian kerentanan sosial $28.1 \%$, dan kerentanan ekonomi sebesar $21.7 \%$. Hasil penentuan bobot dan skor dari masing-masing kerentanan disajikan pada Tabel 3, dan berdasarkan Persamaan 2 selanjutnya bisa didapatkan nilai kerentanan longsor Kota Bogor (Gambar 5).

Tabel 2. Bobot dan skor bahaya longsor

\begin{tabular}{|c|c|c|c|c|c|c|}
\hline \multirow[b]{2}{*}{ Bobot: } & \multicolumn{2}{|c|}{ Parameter Lereng } & \multicolumn{2}{|c|}{ Parameter Penggunaan Lahan } & \multicolumn{2}{|c|}{ Parameter Transportasi } \\
\hline & Lereng & 60.1 & Penggunaan lahan & 26.0 & Jalur Transportasi & 13.9 \\
\hline \multirow{9}{*}{ Skor: } & - Kemiringan & & Tubuh air & 13.6 & - Jenis Jalan & \\
\hline & $0-8 \%$ & 0.33 & Perkebunan, semak & 14.3 & Jalan Lokal & 15.5 \\
\hline & $8-15 \%$ & 0.63 & Sawah & 15.4 & Jalan Kolektor & 31.9 \\
\hline & $15-30 \%$ & 12.8 & Tegalan/tanah kosong & 25.7 & Jalan Arteri \& Jalan Tol & 52.7 \\
\hline & $30-45 \%$ & 25.6 & Permukiman/Gedung & 31.0 & - Jarak Jalur & \\
\hline & $>45 \%$ & 52.0 & & & $10-15$ meter & 16.7 \\
\hline & - Bentuk lereng & & & & 5-10 meter & 32.5 \\
\hline & Lurus & 30.2 & & & & \\
\hline & Cekung & 51.2 & & & & \\
\hline
\end{tabular}




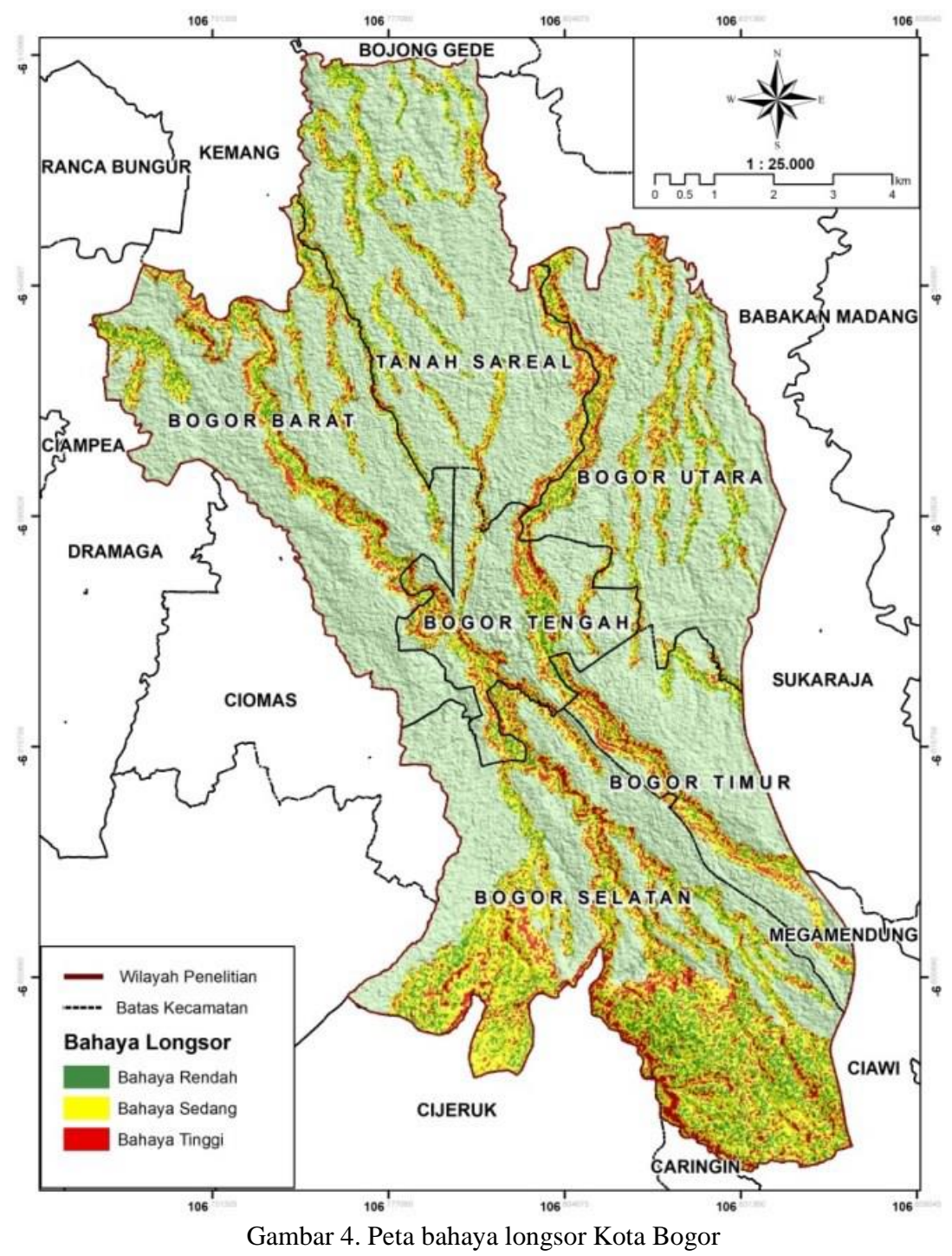

Tabel 3. Bobot dan skor kerentanan longsor

\begin{tabular}{lllllll}
\hline & \multicolumn{2}{l}{ Parameter Kerentanan Fisik (\%) } & \multicolumn{2}{l}{ Parameter Kerentanan Sosial (\%) } & \multicolumn{2}{l}{ Parameter Kerentanan Ekonomi (\%) } \\
\hline Bobot: & Kerentanan Fisik & $\mathbf{5 0 . 2}$ & Kerentanan Sosial & $\mathbf{2 8 . 1}$ & Kerentanan Ekonomi & $\mathbf{2 1 . 7}$ \\
\hline \multirow{3}{*}{ Skor: } & Jalan & 13.4 & $<3,000$ Jiwa & 10.5 & $<25$ juta pertahun & 10.5 \\
& Permukiman & 41.6 & $3,000-6,000$ Jiwa & 25.8 & $25-50$ juta pertahun & 25.8 \\
& Gedung & 45.0 & $>6,000$ Jiwa & 63.7 & $>50$ juta pertahun & 63.7 \\
\hline
\end{tabular}

Dari hasil analisis kerentanan (Gambar 5) didapatkan bahwa kelas kerentanan tinggi yang terluas terdapat di Kecamatan Bogor Utara dengan luas 211 ha atau $51.2 \%$ dari total luas kerentanan kelas tinggi. Kerentanan yang tinggi ini disebabkan oleh penggunaan lahan yang didominasi oleh permukiman serta jumlah penduduk yang juga tinggi, seperti yang tercermin pada peta kerentanan fisik (Gambar 6a) dan kerentanan sosial (Gambar 6b). Luas kelas kerentanan tinggi yang di bawahnya adalah di Kecamatan Bogor Timur dengan luas 107.3 ha (26\%), Kecamatan Bogor Selatan 68.8 ha (16.7\%), dan Kecamatan Bogor Tengah seluas 25.4 ha (6.2\%). Persebaran kelas kerentanan akhir (gabungan kerentanan fisik, sosial, dan ekonomi) Kota Bogor di sajikan pada Gambar 7.

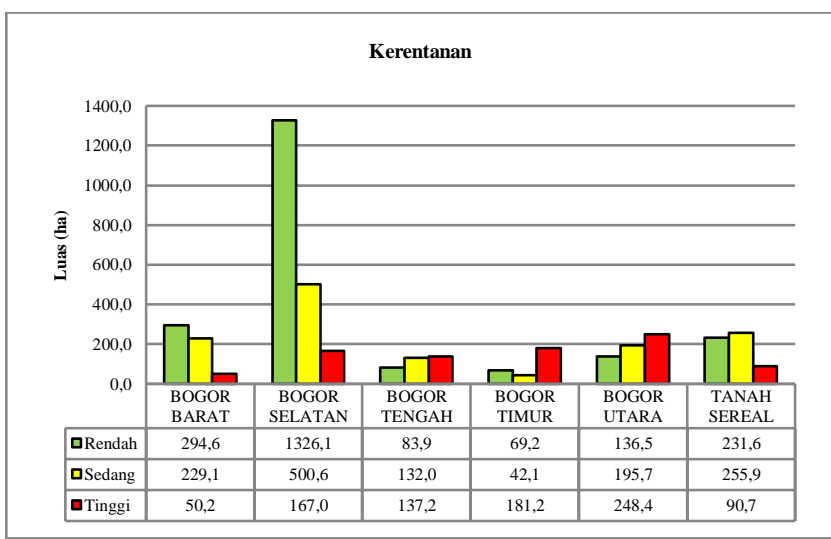

Gambar 5. Kelas kerentanan di Kota Bogor 


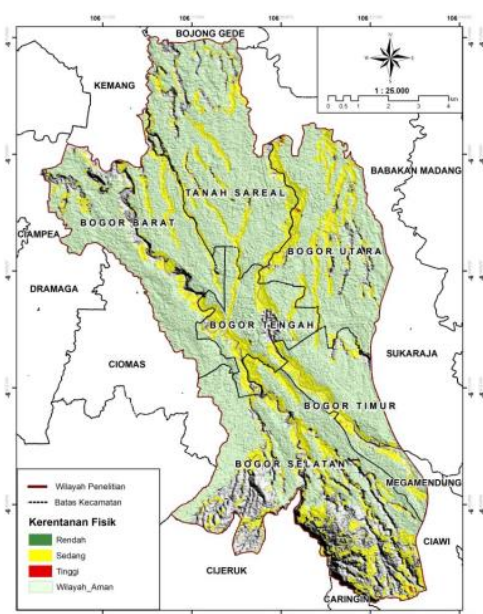

(a)

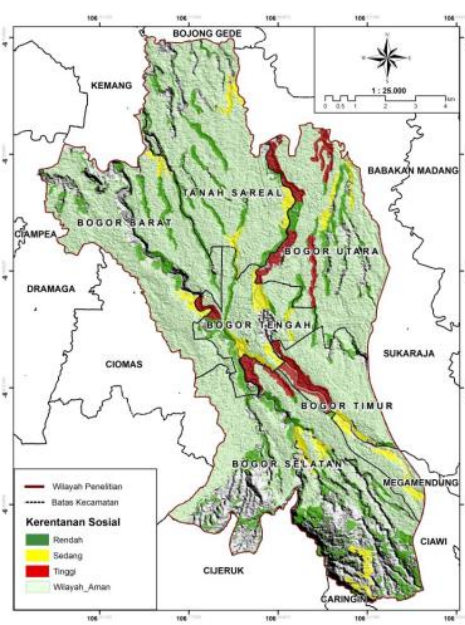

(b)

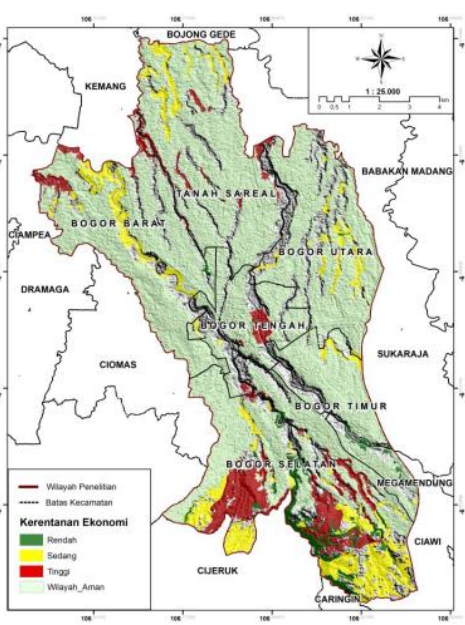

(c)

Gambar 6. Hasil analisis spasial kerentanan longsor: (a) kerentanan fisik, (b) kerentanan sosial, (c) kerentanan ekonomi

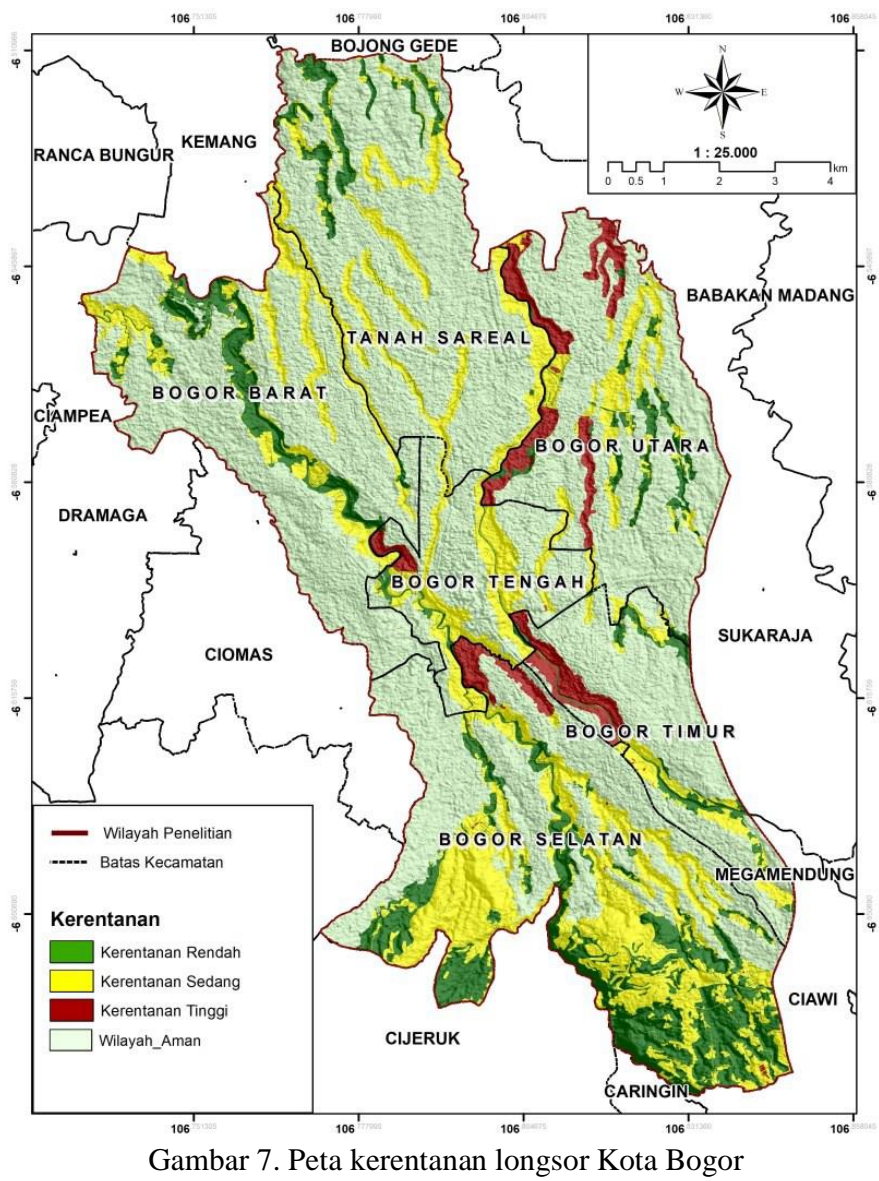

\section{Risiko Longsor}

Penilaian risiko longsor dalam penelitian ini mengacu pada BNPB (2012) dan tingkat risiko dipilah menjadi 3 kelas, yaitu kelas rendah, sedang, dan tinggi. Hasil analisis risiko ditunjukkan pada Gambar 8 dimana dalam gambar terlihat bahwa risiko tinggi yang memiliki luas terbesar terdapat di Kecamatan Bogor Utara, yaitu seluas 125.3 ha atau $40.4 \%$ dari total luas kelas risiko tinggi. Fakta yang menarik adalah bahwa di kecamatan ini wilayah yang mempunyai kelas bahaya tinggi luasannya tergolong kecil dibandingkan dengan kelas bahaya tinggi di kecamatan lainnya. Hal ini menunjukkan bahwa nilai kerentanan yang meningkatkan kelas risiko di Kecamatan Bogor Utara ini, terutama bersumber dari kerentanan sosial dan fisik yang direpresentasikan oleh penggunaan lahan permukiman. Jika dilihat dari data demografi, areal pemukiman di Kota Bogor ini diprediksi akan terus berkembang di waktu yang akan datang, dikarenakan nilai Growth Rate (GR) di Kecamatan Bogor Utara adalah sebesar 2.57\% dari tahun 2000 hingga 2010 (BPS Kota Bogor, 2017), dimana nilai ini tertinggi kedua setelah Kecamatan Tanah Sareal yang mempunyai nilai GR 3.38\%. Dengan melihat angka-angka tersebut maka risiko longsor di Kota Bogor ke depan menjadi ancaman dan sekaligus menjadi tantangan untuk menanggulanginya. 


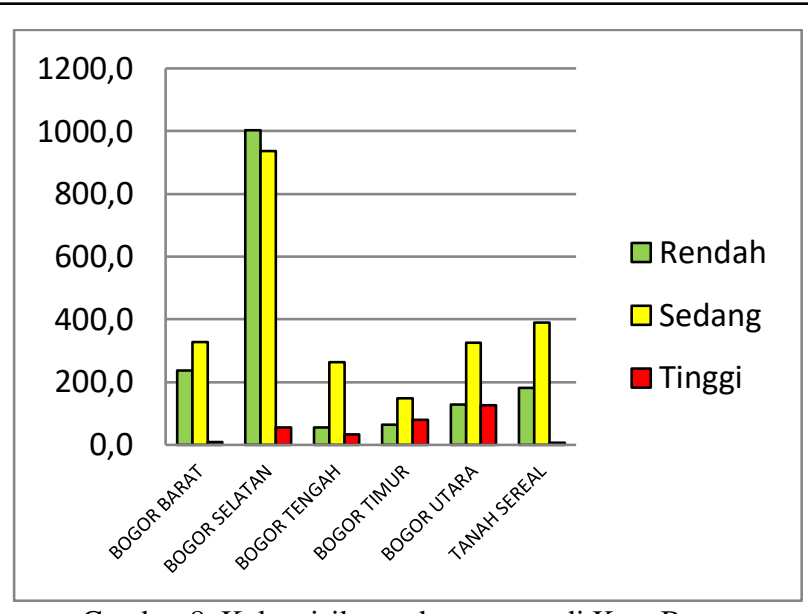

Gambar 8. Kelas risiko perkecamatan di Kota Bogor

Selain itu wilayah Kecamatan Bogor Utara secara geografis juga merupakan wilayah terdekat dengan Ibu Kota Jakarta, sehingga kedekatan dengan Ibu Kota ini, juga memicu perubahan penggunaan lahan yang dinamis. Kepadatan penduduk di kota Jakarta yang sangat tinggi dan tingginya harga tanah di DKI juga membuat sebagian besar penduduk tidak mampu untuk memiliki tempat tinggal di Jakarta, sehingga mereka mencari tempat tinggal di wilayah penyangganya, di kota dan kabupaten sekitarnya, termasuk di Kota Bogor. Fenomena seperti ini yang menjadikan gejala sub-urbanisasi terjadi dengan sangat cepat.

Fenomena sub-urbanisasi ini dapat dilihat salah satunya dari fakta demografis dimana laju pertumbuhan penduduk Kabupaten Bogor yang dalam kurun waktu 10 tahun (2000 - 2010) mencapai angka sebesar 3.15\% per tahun yang menempati peringkat tertinggi di Provinsi Jawa Barat (BPS Provinsi Jawa Barat, 2014). Melihat fenomena seperti ini, maka perencanaan wilayah perlu mendapat perhatian yang serius dan dirumuskan dengan matang. Jika penataan ruang ini kurang diperhatikan, maka pertumbuhan penduduk yang cepat akan meningkatkan nilai risiko di wilayah Bogor, karena area-area rawan longsor akan berpeluang untuk dikonversi menjadi suatu area permukiman. Hasil analisis spasial wilayah risiko longsor di Kota Bogor disajikan pada Gambar 9.

\section{Arahan Mitigasi}

Untuk mengatasi tingginya tingkat risiko, upayaupaya mitigasi bencana sangat diperlukan. Arahan mitigasi bencana longsor untuk Kota Bogor dapat dirumuskan setelah mengetahui persebaran kelas risiko, dimana bentuk mitigasi disesuaikan dengan tingkat bahaya maupun kerentanan longsor di setiap wilayah. Dalam penelitian ini mitigasi diarahkan ke dalam 3 bentuk teknik, yaitu sipil, vegetatif, dan sosial. Dari ketiga bentuk dasar ini selanjutnya disusun model arahan yang sifatnya dapat tunggal atau pun kombinasi dari ketiga teknik tersebut.
Secara keseluruhan terdapat 4 model arahan mitigasi yang disesuaikan dengan kondisi risiko di masing-masing kecamatan. Metode penentuan arahan mengacu pada Tabel 2 dan diterapkan untuk area yang berisiko sedang dan tinggi. (Tabel 4).

Dari Tabel 4 dapat dilihat bahwa Kecamatan Bogor Selatan menjadi area terluas yang harus mendapat perlakuan mitigasi seluas 641.8 ha, sedangkan sisanya seluas $1,351.9$ ha $(59.1 \%)$ dianggap masih belum memerlukan tindakan mitigasi. Area terluas kedua dan seterusnya adalah di Kecamatan Bogor Utara dengan luas 409.8 ha (19.7\%), Kecamatan Tanah Sareal 300.7 ha (14.4\%), Kecamatan Bogor Barat 258.5 ha (12.4\%), Kecamatan Bogor Tengah 254.3 ha (12.2\%), dan Kecamatan Bogor Timur 219.1 ha (10.5\%).

Arahan mitigasi tersebut di atas sangat cocok untuk diterapkan di wilayah-wilayah yang dominan dengan permukiman atau lahan terbangun seperti halnya kondisi di Kota Bogor. Dalam hal ini untuk area-area bahaya tinggi masih bisa dimanfaatkan meskipun membutuhkan konstruksi yang memadai, bahkan pada lahan-lahan tertentu bisa digunakan sebagai lahan produktif dengan menerapkan teknik vegetatif, yaitu memanfaatkan lahan sebagai areal kebun campuran. Namun demikian penerapan arahan mitigasi ini tetap perlu perhitungan dengan lebih detail di lapang terutama terkait dengan rancangan konstruksi dan sumber daya yang dibutuhkan. Secara utuh persebaran spasial arahan mitigasi bencana longsor Kota Bogor disajikan pada Gambar 10.

\section{SIMPULAN}

Daerah rawan longsor di Kota Bogor mengikuti pola bentuklahan. Kerawanan tinggi berada pada bentuklahan lereng bawah kerucut vulkanik denudasional, tebing sungai, serta lembah dan teras alluvial. Secara administratif wilayah yang mempunyai tingkat kerawanan dan bahaya tertinggi berada di Kecamatan Bogor Selatan. Hasil analisis kerentanan menunjukkan bahwa wilayah yang paling rentan adalah Kecamatan Bogor Utara. Dalam hal ini faktor permukiman dan jumlah penduduk menjadi faktor yang paling penting menentukan nilai kerentanan

Hasil penilaian risiko menunjukkan bahwa Kecamatan Bogor Utara mempunyai kelas risiko tinggi yang terluas di Kota Bogor. Faktor yang berpengaruh besar menaikkan nilai risiko di kecamatan ini adalah faktor kerentanan. Hal ini menunjukkan bahwa aspek pertumbuhan penduduk dan permukiman perlu mendapat perhatian untuk penurunan risiko ke depan.

Ada 3 bentuk teknik mitigasi yang disarankan untuk Kota Bogor yang memiliki penggunaan lahan dominan berupa lahan terbangun, yaitu teknik sipil, teknik vegetatif, dan teknik sosial terutama untuk daerah yang mempunyai risiko sedang dan tinggi. 


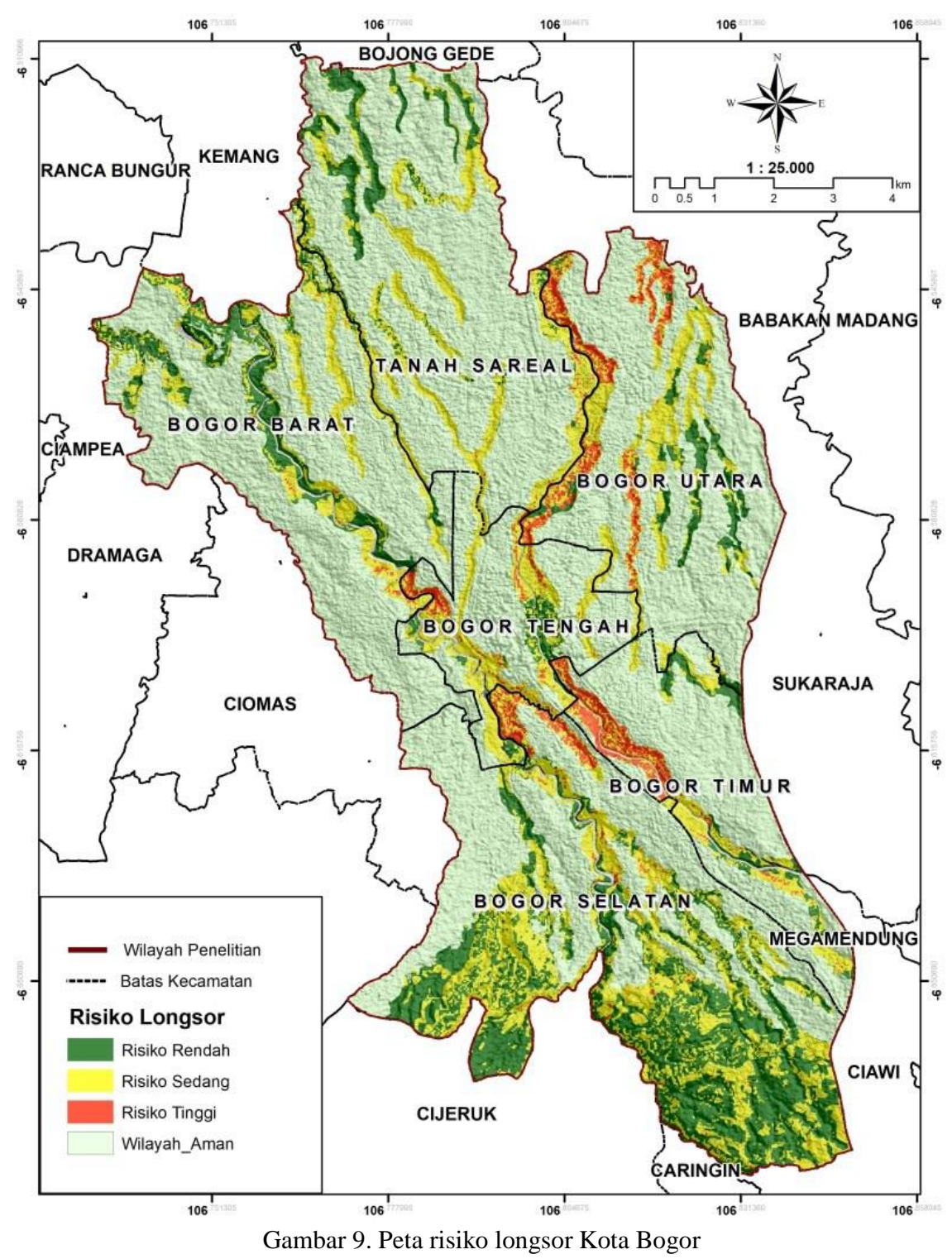

Tabel 4. Luas area yang perlu mendapat tindakan mitigasi bencana longsor dan bentuk mitigasinya

\begin{tabular}{ccrrrrrr}
\hline \multirow{2}{*}{ No. } & \multirow{2}{*}{ Kecamatan } & \multicolumn{5}{c}{ Arahan Bentuk Mitigasi } & \multirow{2}{*}{ Luas Arahan Mitigasi (ha) } \\
\cline { 2 - 6 } & Bidak Perlu Mitigasi & T. Sip & T. Veg; T. Sip & T. Veg; T Sip; T Sos & T. Veg; T Sos & 258.5 \\
2 & Bogor Barat & 315.5 & 42.7 & 171 & 36.9 & 7.9 & 641.8 \\
2 & Bogor Selatan & $1,351.9$ & 114.9 & 369.7 & 132.8 & 24.4 & 254.2 \\
3 & Bogor Tengah & 98.8 & 33 & 104.8 & 102.6 & 13.8 & 219.1 \\
4 & Bogor Timur & 73.5 & 27.5 & 33 & 141.2 & 17.4 & 409.8 \\
5 & Bogor Utara & 170.8 & 24.3 & 150.7 & 190.2 & 44.6 & 300.7 \\
6 & Tanah Sareal & 277.6 & 18.4 & 197 & 75.4 & 9.9 & $2,084.1$ \\
\hline \multicolumn{2}{r}{ Total Luas (ha) } & $2,288.1$ & 260.8 & $1,026.2$ & 679.1 & 118.0 & \\
\hline
\end{tabular}




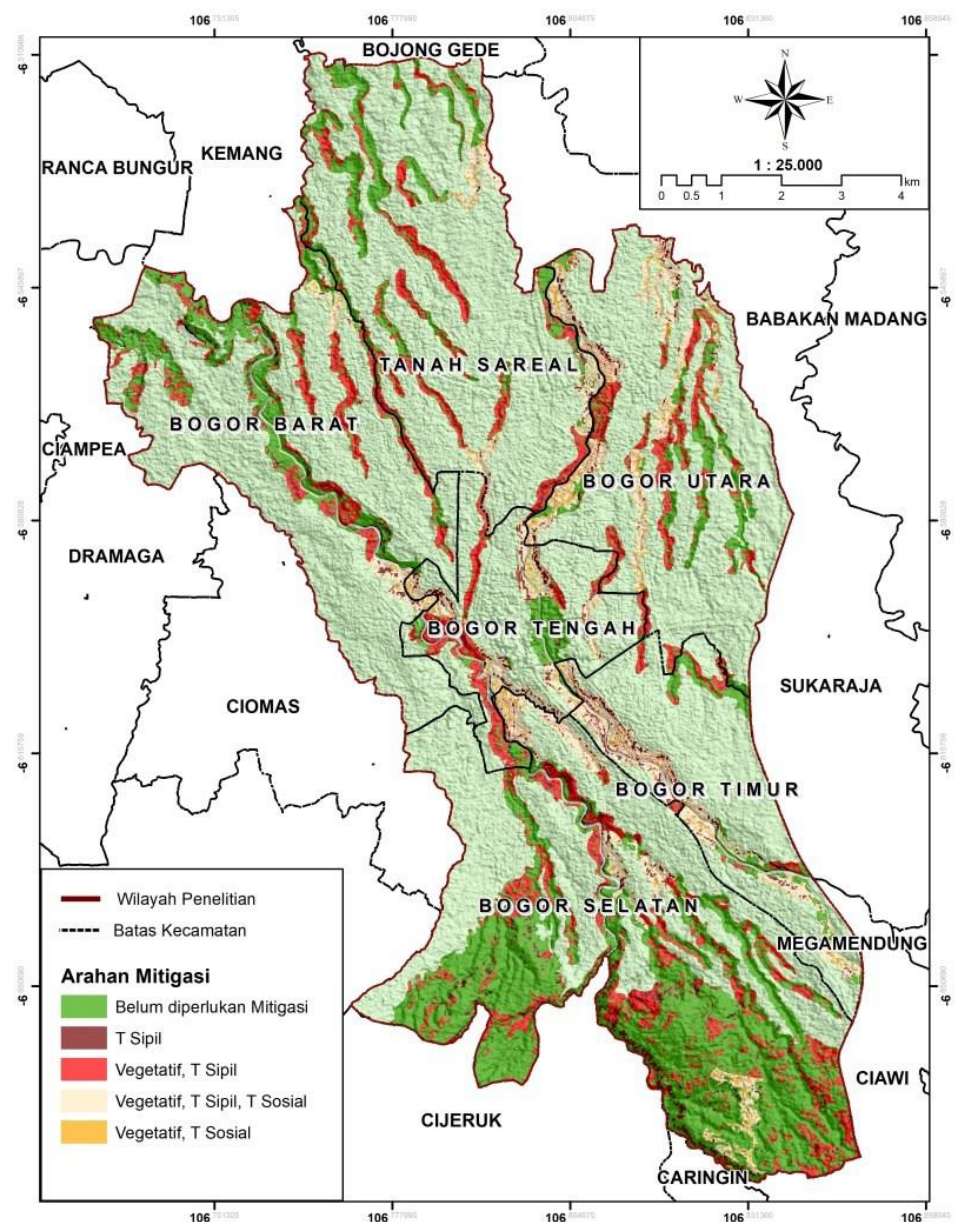

Gambar 10. Persebaran spasial bentuk-bentuk mitigasi bencana longsor di Kota Bogor

\section{DAFTAR PUSTAKA}

[BNPB] Badan Nasional Penanggulangan Bencana. 2012. Peraturan Kepala Badan Nasional Penanggulangan Bencana No. 02 Tahun 2012 tentang Pedoman Umum Pengkajian Risiko Bencana. BNPB, Jakarta.

[BNPB] Badan Nasional Penanggulangan Bencana. 2016a. 2,342 Kejadian Bencana Selama 2016, Rekor Baru.

https://www.bnpb.go.id/home/detail/3233/2.342Kejadian-Bencana-Selama-2016,-Rekor-Baru-. [diakses tanggal 15 Agustus 2017].

[BNPB] Badan Nasional Penanggulangan Bencana. 2016b. Risiko Bencana Indonesia. BNPB, Jakarta.

[BPBD] Badan Penanggulangan Bencana Daerah Kota Bogor. 2017. Data kejadian bencana. BPBD, Kota Bogor.

[BPS] Badan Pusat Statistik Provinsi Jawa Barat. 2014. Jawa Barat Dalam Angka 2014. BPS, Bandung.

[BPS] Badan Pusat Statistik Kota Bogor. 2017. Kota Bogor Dalam Angka 2017. BPS, Kota Bogor.

Dibyosaputro, S. 1999. Longsor Lahan di Daerah Kecamatan Samigaluh kabupaten Kulon Progo,
Daerah Istimewa Yogyakarta. Majalah Geografi Indonesia UGM, Yogyakarta.

[KLHK] Kementerian Lingkungan Hidup dan Kehutanan. 2015. Rencana Strategis Direktorat Jenderal Pengendalian Daerah Aliran Sungai dan Hutan Lindung tahun 2015-2019. KLHK, Jakarta.

Ramlan, A., M.S. Solle dan Seniarwan. 2015. Dinamika dan proyeksi perubahan penggunaan lahan di kawasan peri-urban Kota Makassar (Kawasan Mamminasata). Dalam Prosiding Pertemuan Ilmiah Tahunan XX 2015. Universitas Hasanuddin, Makassar.

Saaty, T.L. 1977. A scalling method for priorities in hierarchical structures. J. Math. Psycol., 5: 231281.

Sari, V.P. 2016. Analisis risiko dan arahan mitigasi longsor di Kabupaten Agam Provinsi Sumatera Barat [Tesis]. IPB. Bogor.

Shaw, S.C. and H.D. Johnson. 1995. Slope Morphology Model Derived from Digital Elevation Data. Washington Department of Natural Resources. http://citeseerx.ist.psu.edu/viewdoc/summary?doi $=10.1 .1 .530 .1458$ (diakses 8 Desember 2017). 